\title{
ARTES DE INTERVENÇÃO, INVENTAR CIDADES
}

Deisimer Gorczevski ${ }^{1}$

Aline Mourão Albuquerque ${ }^{2}$

João Miguel Diógenes de Araújo Lima ${ }^{3}$

Reaver a cidade é a reaver a política, habitamos a cidade que nos habita, atravessamos a cidade que nos atravessa, existimos como ${ }^{4}$ pele|muro, mar|artérias|riachos, mangue|pulmão, fraturas, fissuras, edificações e ruínas, paixão e desencanto, memória e esquecimento, estamos tão fortes quanto sensíveis na experiência cotidiana de nos inventarmos com as cidades que coabitamos, percorremos inúmeros $\mathrm{km}$ de terra, areia, praia, praças, árvores exuberantes, rodovias, ferrovias, somos morros, pontes, viadutos, farol a iluminar espaços esquecidos, terrenos baldios, crianças nos sinais, prédios inconclusos, vendedores ambulantes, cadeiras nas calçadas, loja sem paredes, somos tudojuntoemisturado, e o denso caldo que nos compõe também alimenta a utopia que avistamos todos os dias à linha do horizonte de cores incríveis, ao alcance de nossos sonhos, intenções, delírios, pirações, gambiarras, intervenções. Assim como a matéria demasiada humana nos constitui e nos faz essencialmente imperfeitos e complexos, do mesmo modo a cidade que somos, como um espelho de Narciso, é imperfeita e complexa e nos instiga a nos inventarmos fortalezas sensíveis e criarmos uma espécie de constelação de desejos que se quer capaz de reluzir afetos em tempos de brutalidades.

\footnotetext{
${ }^{1}$ Universidade Federal do Ceará, Brasil. Email: deisimergorczevski@gmail.com ORCID id: https://orcid.org/0000-0002-7433-8798

${ }^{2}$ Universidade Federal do Ceará, Brasil. Email: alialbu@gmail.com ORCID id: https://orcid.org/0000-0001-8956-204X

${ }^{3}$ Universidade Federal do Ceará, Brasil. Email: jmlimabr@gmail.com ORCID id: https://orcid.org/0000-0002-4768-7589

${ }^{4}$ Agradecemos a Nataska Conrado e Salvia Braga, com quem escrevemos a pesquisa Fortaleza Sensíveis: Intervenções com a Cidade; a Pedro Fernandes, Fabíola Gomes e Sabrina Araújo, com quem escrevemos|realizamos a pesquisa Cinema In(ter)venção: Cine Ser Ver Luz; e também a Raul Soagi, criador de uma das imagens do texto.
} 
Jacques Rancière (2012) provoca pensarmos o conhecer como um aventurarse com o mundo, com a enorme floresta de coisas e signos que habitamos; e a ignorância, apenas a distância entre o que já sabemos e o que não sabemos ainda. Uma pesquisa pode ser compreendida, então, como plano de expedição a esse espaço desconhecido, de invenção de possíveis. Assim nos propomos, artistas/pesquisadores, a ocupar e nos ocuparmos da cidade com o intuito de experimentá-la, marcá-la, descrevê-la, senti-la, cartografá-la, escrevê-la, para então reinventá-la - como diz a poeta Cecília Meireles (2002: 45), "a vida só é possível reinventada", assim como as cidades e nós mesmos. Contaremos do que vivemos em diferentes linguagens, do que pensamos do que vimos e do que fazemos com o que pensamos.

\begin{abstract}
O mestre ignorante capaz de ajudá-lo a percorrer esse caminho é assim chamado não porque nada saiba, mas porque abdicou do "saber da ignorância" e assim dissociou sua qualidade de mestre de seu saber. Ele não ensina seu saber aos alunos, mas ordena-lhes que se aventurem na floresta das coisas e dos signos, que digam o que viram e o que pensam que viram, que o comprovem e o façam comprovar. O que ele ignora é desigualdade das inteligências. Toda distância é uma distância factual, e cada ato intelectual é um caminho traçado entre uma ignorância e um saber, um caminho que abole incessantemente, com suas fronteiras, a fixidez e a hierarquia das posições (Rancière, 2012: 15-16, grifo nosso).
\end{abstract}

As expedições/pesquisas do Laboratório de Artes e Micropolíticas Urbanas $(\text { LAMUR })^{5}$ são proposições que desejam pensar e viver Fortaleza - nossa cidade solar, de mares, maresias e mangues, de coisas e signos - como território de conhecer|fazer, de se aventurar; como território de territórios com os quais pensar, sentir, caminhar, conversar, tatear, atravessar, sonhar, conviver, parar, passear, visitar, ornamentar, jogar, compartilhar, observar, inspirar, expirar, estranhar, intervir, marcar e atualizar marcas, “administrar o à toa, o em vão, o inútil”" (Barros, 2016), escutar, ressoar, narrar e dizer algumas de suas histórias, reminiscências, seus agoras e devires.

Nossa pergunta de partida: como a arte contemporânea pode inventar Fortalezas Sensíveis, ativando experiências estéticas e afetivas e tensionando limites e aproximações entre territórios geopolíticos e existências? Trata-se de compreender territórios como Fortalezas Sensíveis, com as quais estamos, visitamos e vivemos, sobretudo, as que nos transpassam pelas afetividades e pela vida cotidiana com suas ruas, bairros, praças, praias, terrenos, edificações, paisagens, árvores, animais, pessoas,...

\footnotetext{
${ }^{5}$ Amparado no Programa de Pós-Graduação em Artes, vinculado ao Instituto de Cultura e Arte (ICA), na Universidade Federal do Ceará - UFC. Mais detalhes no site https://www.lamur-ufc.com/; no Instagram: instagram.com/lamur.ufc/; e no Facebook: facebook.com/lamurufc/
} 
Interessa-nos, assim, inventar cidades com esse conceito, pensando tanto as Fortalezas que ativam nossos sentidos com boas sensações, que resistem e lutam em tantas frentes pelas vidas, pelas sombras, paragens e passagens, pelos espaços de convivência que promovam diferenças e por tantos outros direitos vitais, como as Fortalezas "sensíveis insensíveis", enrijecidas, naturalizadas e talvez convenientemente acomodadas para que se prevaleçam formas do "nada resta fazer". Muitas delas, com isso, desgarradas de nossas existências, de nossos corpos e desejos; algumas delas nutridas por dados estatísticos que, intencionalmente ou não, tentam dar conta de representar, explicar e orientar dimensões humanas, sociais, econômicas, políticas, culturais, todas essas que provavelmente sempre extrapolam, de uma forma ou de outra, números, gráficos, perspectivas e previsões.

A mesma beleza que nos embevece é usada para atrair investimentos que aprofundam o abismo da desigualdade social, e recorremos aqui ao auxílio luxuoso da literatura para imprimirmos uma visualidade ao pensamento sobre nossa pesquisa - "todo abismo é navegável a barquinho de papel”, nos diz João Guimarães Rosa (2017: 63) no conto "Desenredo". Navegamos pelos abismos de uma das cidades mais desiguais da América Latina em nossas pesquisas/expedições, com esse possível, um barquinho de papel, que atravessa distâncias, tensiona limites, afunda, se desfaz, vira bicho, vira chapéu, e reinventa-se sempre, porque temos a arte "para não sucumbirmos junto à verdade", recorda-nos nosso velho companheiro de aventuras, Friedrich Nietzsche (2008: 441).

Do ponto de vista da micropolítica, uma sociedade se define por suas linhas de fuga, que são moleculares. Sempre vaza ou foge alguma coisa, que escapa às organizações binárias, ao aparelho de ressonância, à máquina de sobrecodificação: aquilo que se atribui a uma "evolução dos costumes", os jovens, as mulheres, os loucos, etc. Maio de 68 na França era molecular, e suas condições ainda mais imperceptíveis do ponto de vista da macropolítica. (Deleuze, Guattari, 1996: 94).

Que ciência é essa que inventamos com o cotidiano, ao resistirmos propositivamente com a cidade, sobre a qual pairam tantas ameaças? Sobre todo terreno à beira-mar paira uma ameaça, sobre o patrimônio histórico, material e imaterial; pairam ameaças sobre comunidades inteiras, sobre a pesca artesanal, sobre vendedores ambulantes, sobre as árvores(!), praças e parques, o mangue e, sobretudo, sobre os grupos dissidentes; pairam ameaças sobre todos nós e, especialmente nesse momento em que o 
Brasil atravessa um intenso retrocesso com ameaças a democracia, que tanto lutamos para conquistar.

Atentos à lógica da política governamental e suas "formas contemporâneas que subjugam a vida ao poder da morte (necropolítica)" (Mbembe, 2016: 146) - que é a lógica neoliberal, a adequar a cidade aos mais ricos, esquecendo as populações que lá habitam antes de reformar, privatizar, higienizar e derrubar o presente, querendo sempre um futuro -, posicionamo-nos ao lado dos que resistem hoje a tantas ameaças. Entendemos que apenas aqui, onde moramos, é possível intervir: no fluxo dos dias, nas urgências, nas delicadezas como nas lutas, ocupar a cidade é ocupar a política, é cuidarmos uns dos outros, educarmos uns aos outros, como lemos tantas vezes pixado pelos muros de nossa cidade, é nós por nós. E a universidade pública deve participar desse processo, inclusive para se fortalecer, pois que a ameaça também paira sobre ela. É preciso operar os conceitos aos quais tanto nos afeiçoamos, é preciso azeitar nossa máquina de guerra! É preciso estar atento, forte e sensível.

Fortaleza, enquanto cidade, essencialmente estriada (Deleuze; Guattari, 1995), mas que constantemente se transveste em espaço liso com seus habitantes, percursos nômades, intervenções, criações de frestas em meio à cidade apressada. Um muro, errâncias, narrativas, o sensível em meio à imponência de uma cidade forte como seu nome anuncia.

Paola Jacques (2012: 12) discute alteridade na cidade através de práticas erráticas, na potência de "construção e (contra)produção de subjetividades, sonhos e desejos", na busca por espaços invisibilizados, zonas opacas, intensas e vivas, lugar de criação e diversas possibilidades, espaços alisados da cidade estriada, que se faz na experimentação, na caminhada como prática de experimentação da cidade, enfatizando a experiência do corpo e "reafirmando a potência da vida coletiva, uma complexidade e multiplicidade de sentidos que confronta qualquer pensamento único" (Jacques, 2012: 21).

Nesse sentido, o modo de pesquisar e intervir que experienciamos com o LAMUR, aproxima-se do modo como Hélio Oiticica se colocou como artista no mundo. Essa aproximação nos é muito cara, pois entendemos que as mais radicais proposições de Oiticica são um salto para a compreensão de uma "arte ambiental", que acontece no espaço público: 
[...] pretendo estender o sentido de "apropriação" às coisas do mundo com que deparo nas ruas, terrenos baldios, campos, o mundo ambiente, enfim - coisas que não seriam transportáveis, mas para as quais eu chamaria o público à participação - seria isso um golpe fatal ao conceito de museu, galeria de arte, etc., e ao próprio conceito de "exposição" - ou nós o modificamos ou continuamos na mesma. Museu é o mundo, é a experiência cotidiana. [...] (Oiticica apud Favaretto, 2015: 129).

As proposições de Oiticica vibram harmoniosamente na sintonia de nossas experimentações à medida que nos "apropriamos" de modo relacional, propositivo, de espaços urbanos esquecidos. Colocamo-nos no fluxo dos acontecimentos, esperando que os dispositivos de que lançamos mão causem atritos com o real, produzam faíscas de outros possíveis, despretensiosamente intencionados, atentos, fortes, mas que, um tanto distraídos, venceremos ${ }^{6}$.

Ao afirmarmos as proposições de Oiticica e nos apresentarmos como laboratório que realiza pesquisas e intervenções, vinculado à Universidade Federal do Ceará, no Instituto de Cultura e Arte (ICA) via Programa de Pós-Graduação em Artes (PPGArtes), outras questões emergem e, entre elas, queremos pensar como pesquisar e intervir pode ativar experiências estéticas com diferentes espaços-tempos da cidade e da universidade. Essa questão se desdobra da pesquisa Arte | Espaço Comum | IntenCidades, realizada de 2014 a 2016, trazendo temáticas e experiências que colaboram com o exercício de pensar a relação entre pesquisar e intervir como potência que nos impele a produzir conexões entre arte e cidade, pensando os espaços-tempos da cidade e da universidade, processos de criação e resistência e movimentos artísticos, sociais, históricos e contemporâneos.

Consideramos, em nossas pesquisas, alguns conceitos, entre eles, o de “experiência estética”, analisado a partir das contribuições de John Dewey (1934/2005); o exercício de um diálogo com os estudos de Humberto Maturana e Francisco Varela (1990; 1997), pensando a "autopoiese", "biologia do conhecer" e "enação"; bem como a noção de "atenção", problematizada por Virginia Kastrup (2012), autora que procura tornar visível a potência de transformação que a arte possui, tanto para o artista como para o "percebedor". Nas palavras de Kastrup (2012: 28), a “[...] experiência estética surpreende pela beleza ou pelo estranhamento, mas sempre por seu caráter de enigma,

\footnotetext{
${ }^{6}$ Também inspirados em Paulo Leminski (1990), cuja poética se constrói com a cidade, seus prazeres e seus conflitos, relação presente também no poema "Ainda vão me matar numa rua/Quando descobrirem, principalmente, /que faço parte dessa gente que pensa/que a rua é a parte principal da cidade" (Leminski, 2013: 24).
} 
que mobiliza a atenção e desativa a atitude recognitiva natural. Ela instala um estado de exceção".

Até aqui, falamos dos territórios de nossa pesquisa/expedição, a vasta abrangência de seus espaços semoventes e seus deslimites, por entendermos que uma cidade é um território vivo, como um rio, no qual não se entra duas vezes do mesmo modo. A partir daqui falaremos dos modos como propomos trilhar esses territórios, como nos acompanhamos uns dos outros, como convidamos outros a nos acompanharem, o que usamos para caminhar, que dispositivos inventamos, que conceitos operamos, como iluminamos quando escuro, que marcas escolhemos para sinalizar, como partilhamos a experiência dos percursos.

\section{Modos de intervir e pesquisar COM}

Em nosso processo de criação artística, pesquisar e intervir entrelaçam-se intimamente com os modos de viver e conviver, em nossas cidades, instigando encontros e conversas, experimentações com materiais, debates e partilhas com outros artistas ou o público mais amplo. Ateliês, museus e galerias, que foram e continuam sendo espaços dedicados às artes, no século XX foram particularmente desafiados a se abrir - às vezes de dentro para fora, às vezes de fora para dentro.

Esse período também viu o surgimento de formações em artes nas universidades, em cursos de graduação e pós-graduação. Artistas-professores e estudantes-artistas passaram a compor o ensino superior. Essas instituições, constituídas por redes de conversações (Andrade et al., 2002: s/p), comportam não apenas relações de trabalho marcadas por demandas institucionais, como também podem se constituir de conversações acadêmico-científicas dedicadas à aprendizagem e à poiesis.

Entre os critérios acadêmicos e os critérios artísticos, qual é o lugar do artista na universidade? Para o artista-professor Ricardo Basbaum (2013),

Não é tarefa simples [...] construir um espaço de pesquisa em artes, na universidade, que mantenha em aberto os canais com o circuito de arte: há escassez de conexões preparadas para conduzir as ligações entre um e outro setor, com a flexibilidade necessária. (Basbaum, 2013: 200).

Nessa aproximação, “[n]ão há como escapar desta máxima: dentro da universidade, o trabalho de arte se transforma em pesquisa e o artista em pesquisador. Escreve-se 'artista-pesquisador', portanto, e temos aí um outro personagem, com suas 
peculiaridades" (Basbaum, 2013: 194). Trata-se de um deslocamento entre circuitos, em uma multiplicidade de redes.

Nas nossas pesquisas e intervenções atuais, tal como nas pesquisas anteriores, em especial: Arte | Espaço Comum | IntenCidades (2014-2016), Coletivo Audiovisual do Titanzinho - Cine Ser Ver Luz (2014- 2017) e Cinema In(ter)venção: Cine Ser Ver Luz (desde 2017), tomamos o desafio da UniverCidade, uma universidade que se movimente entre a cidade e com a cidade. As artes e a universidade percorrem espaços do fazer cotidiano e da convivência, como ruas, praças, becos, esquinas, casas e construções abandonadas e áreas verdes - espaços não convencionais da arte (Gorczevski et al., 2015).

Movimentar as artes e a universidade com o cotidiano urbano demanda a invenção de modos de fazer. Um dos desafios das nossas pesquisas tem sido pensar acerca das especificidades da arte contemporânea, de como ela nos solicita protocolos distintos de pesquisa, de pensamento, de visão e de invenção de mundo(s).

Acreditamos na "[...] força ácida da arte em flexibilizar impedimentos e afirmar lugares e espaços a partir de passagens e ligações” (Basbaum, 2006: 201). Desse modo, por meio de caminhadas e visitas, passamos a criar vizinhança ${ }^{7}$ com outras disciplinas e saberes, ampliando a pesquisa nas dimensões inter e transdisciplinar, considerando a transversalidade ${ }^{8}$ entre a ciência, a abertura para o social, a estética, a política e a ética. Nossa dedicação se põe menos nas fronteiras e mais no que pode se dar "entre" elas. Tendo a inter e a transdisciplinaridade como ênfase teórico-metodológica, cria-se, neste percurso, um espaço-tempo para novas sensibilidades intervirem no social por meio da produção acadêmica.

Nossas expedições/pesquisas operam em duas linhas de pesquisa, priorizando as temáticas que envolvem processo de criação em artes, micropolíticas urbanas e pesquisa e docência em artes, ciências e filosofia. Com a linha Processos de criação e micropolíticas urbanas, damos conta do objetivo de acompanhar e cartografar pesquisas e intervenções urbanas, analisando processos de criação que problematizem as relações entre arte e vida, arte e política, arte e natureza e a experiência ética e estética do encontro com modos de existência singulares e coletivos, no cotidiano da cidade e da universidade.

\footnotetext{
${ }^{7} \mathrm{Na}$ coletânea "Vocabulário político para processos estéticos", Enrico Rocha (2014: 30) pensa a relação de vizinhança como aquela em que "você negocia o que é comum, as aproximações e também as distâncias necessárias".

${ }^{8}$ O conceito, como compreendido por Guattari (1987: 96), apresenta "uma dimensão que pretende superar os dois impasses, o de uma pura verticalidade e o de uma simples horizontalidade; ela tende a se realizar quando uma comunicação máxima se efetua entre diferentes níveis e sobretudo nos diferentes sentidos".
} 
Já com a linha Processos de criação, pesquisa e docência em artes, ciências e filosofia, a intenção é de problematizar os modos de pesquisar e intervir em processos de aprendizagem, evidenciando os desafios presentes desde a constatação da complexidade das mutações nos modos de conhecer e se relacionar com a arte, a ciência e a filosofia na contemporaneidade, em especial, considerando questões que rompem com as metodologias e linguagens clássicas e a emergente hibridização de métodos, na perspectiva de um pensamento inter e transdisciplinar.

As nossas pesquisas e intervenções se apresentam como exercícios teóricometodológicos permeados por um diálogo permanente com os recentes estudos da epistemologia, das Artes, da Filosofia, das Ciências Humanas e Sociais, ao mesmo tempo em que problematizamos questões transversais, tais como as relações entre pesquisa, ensino e extensão, o exercício coletivo de construção de conhecimento e a experiência transdisciplinar.

Em vez de se referir a conhecimento, Humberto Maturana $(1999 ; 2001)$ afirma o verbo "conhecer", que vai apresentar novas implicações, próprias do caminho teórico seguido pelo cientista. Ele está empenhado na compreensão de processos e relações. Tal atitude está marcada em sua recusa aos substantivos linguagem, cognição, conhecimento, emoção, vida, substituindo-os por linguajar, conhecer, emocionar, viver.

Investigar as implicações epistemológicas e éticas propostas pela "Biologia do Conhecer" leva-nos a observar, entre seus pressupostos básicos, a produção do conhecimento como inseparável da produção de subjetividade; o próprio ato de perceber e conhecer constitui o percebido numa relação indissociável.

Percorrer trilhas que impliquem olhar não mais para a dicotomia do "um ou outro", mas com a perspectiva de atentar ao "entre", a mútua interdependência do dentro e do fora, leva-nos aos estudos de Francisco Varela $(1992 ; 1994)$. O autor questiona a concepção de representação|cognição, em que pensar a representação é pensar um mundo que já está dado, determinado. E conhecer é inventar, é dar corpo a alguma coisa, é conceber um mundo que não tem forma estabelecida, nenhuma verdade ou essência que deva ser desvendada.

Nos estudos relacionados ao conceito de "enação", o autor afirma a ideia de que existe uma cognição do corpo e considera o "[...] fenômeno cognitivo e o fenômeno 
da vida inseparáveis, pois desde o começo da vida celular do fenômeno autopoiético ${ }^{9}$, vida e conhecimento são duas coisas inseparáveis" (Varela, 1993: 87).

Entre as possibilidades de modos de pesquisar e intervir com, o coletivo de pesquisa considera relevantes as contribuições da cartografia (Deleuze; Guattari, 1996; Deleuze, 1997; Rolnik, 1989, entre outros) como uma das estratégicas do pesquisar e intervir com a cidade, com o bairro, as praças, as ruas e todos que habitam, ocupam e convivem. O cartógrafo compõe mapas dos afetos que lhe acontecem a partir da convivência e da relação que se cria com a pesquisa (Gorczevski; Gois, 2014). Afetar-se faz parte do processo da pesquisa, e é mais ainda, nesse momento, que percebemos que nossas questões são feitas de vida (Lazzaroto; Carvalho, 2012: 27). É importante frisar que, na pesquisa cartográfica, acompanhar processos e habitar o território são alguns dos modos de inventar mapas com os trajetos e devires.

Os mapas não devem ser compreendidos só em extensão, em relação a um espaço constituído por trajetos. Existem também mapas de intensidade, de densidade, que dizem respeito ao que preenche o espaço, ao que subtende o trajeto. (Deleuze, 1997: 86-87).

Também nos interessa a relação da cartografia com a pesquisa intervenção (Passos; Kastrup; Escossia, 2010) e a aproximação com a etnografia (Kastrup, 2008). Ressaltam-se as etnografias sensoriais que, com o conceito de emplacement, tomam o corpo como aquele "que sabe e aprende em movimento, sentindo-se parte de um ambiente, onde ele se 'torna' em relação com outros elementos” (Pink, 2011: 354, tradução nossa ${ }^{10}$ ), bem como as contribuições de Jacques (2012) e Britto e Jacques (2009) na corpografia urbana, que problematizam as relações entre corpo humano e o urbano como relação de mutualidade, em que o corpo inscreve a cidade percorrida, bem como as memórias dessa cidade inscrevem e configuram o corpo que a percorre.

A composição metodológica sugere um exercício artístico-científico que afirma o pesquisar como ato político. E, nesse processo de compor métodos e procedimentos de pesquisa e intervenção, nós nos deparamos com questões abertas, ou seja, perguntas que demandam estar em pesquisa, como: que combinações/analisadores poderão se tornar balizadores de transformações éticas, estéticas e cognitivas na vida?

\footnotetext{
${ }^{9}$ Ver conceitos e especificidades sobre o termo "autopoiético - autopoiese" em Maturana e Varela (1997: 17-21 e 46-48).

10 Tradução de: "one that knows and learns in movement, feeling/sensing her or his way as part of an environment where it 'becomes' in relation to other elements".
} 
Sem pretender trazer respostas rápidas, propomos modos de operar a pesquisa de si e do mundo, tomando como marcadores (Pellanda, 2008; Pellanda, Gustsack, 2015) os conceitos de atenção - esse problematizado por Kastrup (2012) - e observação, como apresentado nos estudos de Maturana (1999; 2001). Também contamos com alguns verbos|conceitos, entre eles, inventar, intervir, resistir, afetar, desejar e coletivizar, presentes em "Pesquisar na Diferença: Um Abecedário", livro organizado por Tania Galli Fonseca, Maria Lívia do Nascimento e Cleci Maraschin (2012). E, ainda, outros verbos|conceitos: "caminhar" e "parar", considerando os estudos de Francesco Careri (2013; 2017), e “conversar e conviver", inspirados na abordagem de Maturana (1999).

Nossos modos de pesquisar e intervir também são receptivos às contribuições que assumem uma "atitude indisciplinar":

[...] tendo em conta a multiplicidade das narrativas, das realidades e das verdades, optamos por uma atitude indisciplinar - segunda a qual, para se realizar um projeto, não se cessa de urdir várias disciplinas, artísticas ou não, como se tecem várias interações na construção de uma jornada. No entanto, uma característica recorrente de nossa prática artística se situa no fato de propor a obra em execução, quer pensemos na performance, que pelo gesto e ação oferece ao público as condições de sua realização; ou através da criação de situações ao seio das quais o indivíduo é convidado seja a construir, seja a participar no processo da obra, e isso, acontece tanto em lugares reputados da arte, como em contextos do cotidiano, incluindo a internet. (Doyon/Demers, 2009: 6).

O encontro com os estudos de Hélène Doyon e Jean-Pierre Demers, além de proporcionar questões específicas em temas voltados à metodologia e a métodos de pesquisa em artes e à proposição de uma "atitude indisciplinar", propiciou um contato inicial com o conceito de manoeuvre e os estudos de seu criador, Alain-Martin Richard (2017). Para ele, “[...] a visibilidade da arte em um espaço público não é o bastante para criar um novo paradigma. A qualidade da relação, e as formas como a arte intervém devem ser modificadas" (Richard, 2017: 11), o que instigou o desejo por avançar na problematização do conceito de intervenção urbana, tendo como diálogo um pensamento em artes de intervenção.

Nos estudos e intervenções de Doyon/Demers (2009), podemos constatar como o conceito de manoeuvre opera e complexifica questões antes pouco visíveis, como a percepção da existência de "microcomunidades" e, nelas, a intensidade da vida e da convivência. A proposição dos autores nos coloca em contato com modos de operar manoeuvre, desde os primeiros sentidos e, em suas experimentações, o termo recebe complexidade: 
Se bem que o primeiro sentido do termo manobra refira-se à "ação sobre as cordas, velas, leme, etc., destinando-se a regular o movimento do navio", para Alain-Martin Richard, a manobra "é uma ação que age potencialmente em todos os campos do saber e da produção. Particularmente, a manobra não espera por espectadores, ela se acha ao meio de caminhos que não levam a lugar nenhum, para evocar Heidegger. Quer dizer, ela está ao centro mesmo daquilo que advém. $O$ público não está convidado para a manobra, como o estaria para uma performance, um happening ou para um vernissage. Por se encontrar subitamente envolvido e participando da ação, ele se subtrai do outro - artista e não-artista com quem a obra se constrói. Tributária do interesse, mas sobretudo da intenção que ela evidencia, a manobra "se coloca como um projeto de forma de vida que somente se cumprirá quando for assumida, em sua dinâmica, por uma comunidade". Consequentemente, sua duração permanecerá indeterminada. (Doyon/Demers, 2009: 193).

Apresentamos, a seguir, um conjunto de ações propostas e realizadas pelo Laboratório Artes e Micropolíticas Urbanas (LAMUR): o encontro ConversAções na Praia do Vizinho e as intervenções Micropolítica e Revolução. São trilhas por nós desbravadas, no decorrer da pesquisa/expedição, e reinventadas a cada nova travessia.

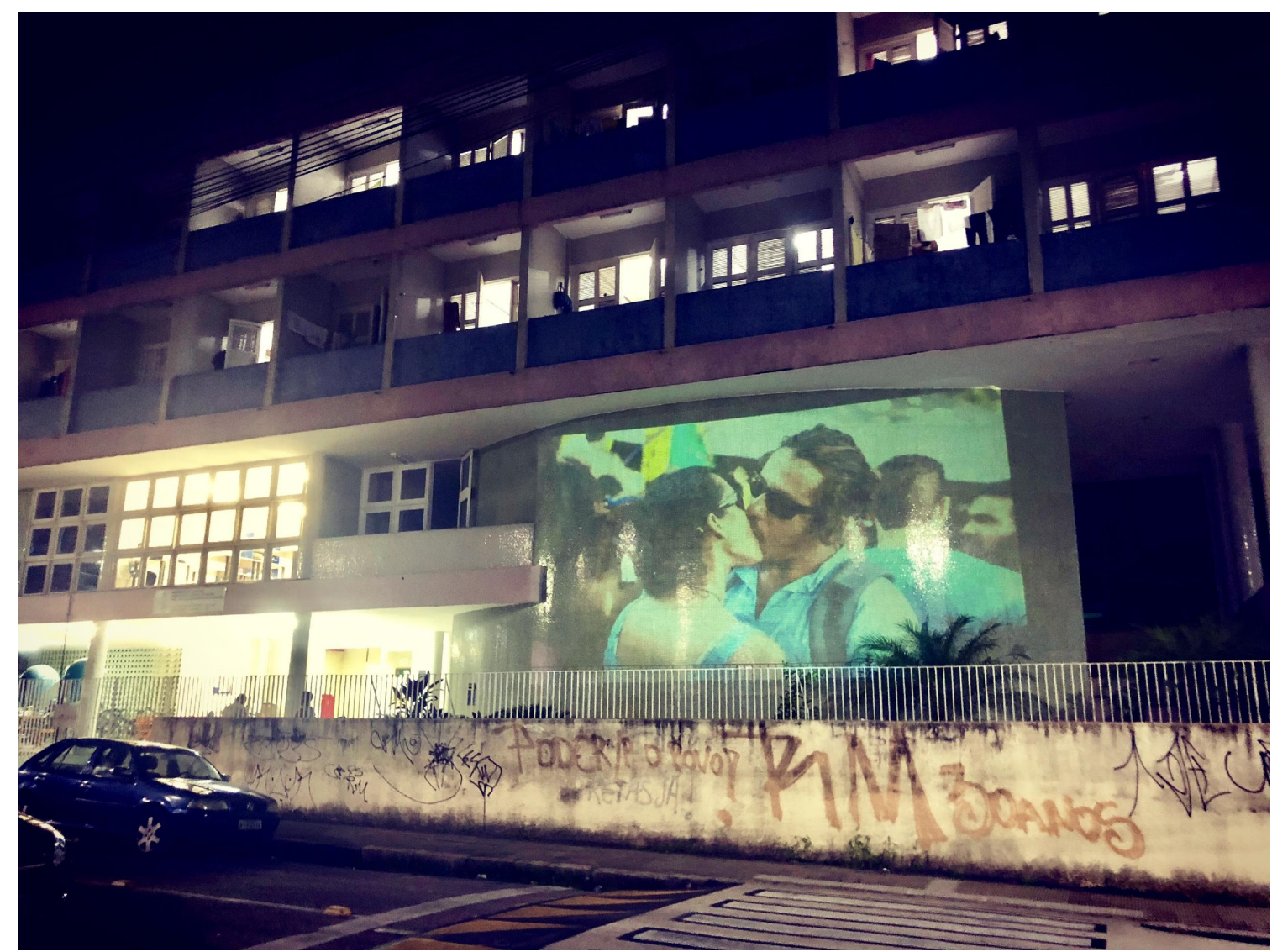

Figura 1 - Um beijo com a Gentilândia. Fotografia de Vitor Grilo projetada no Micropolítica e Revolução. Fonte: Acervo do LAMUR. 

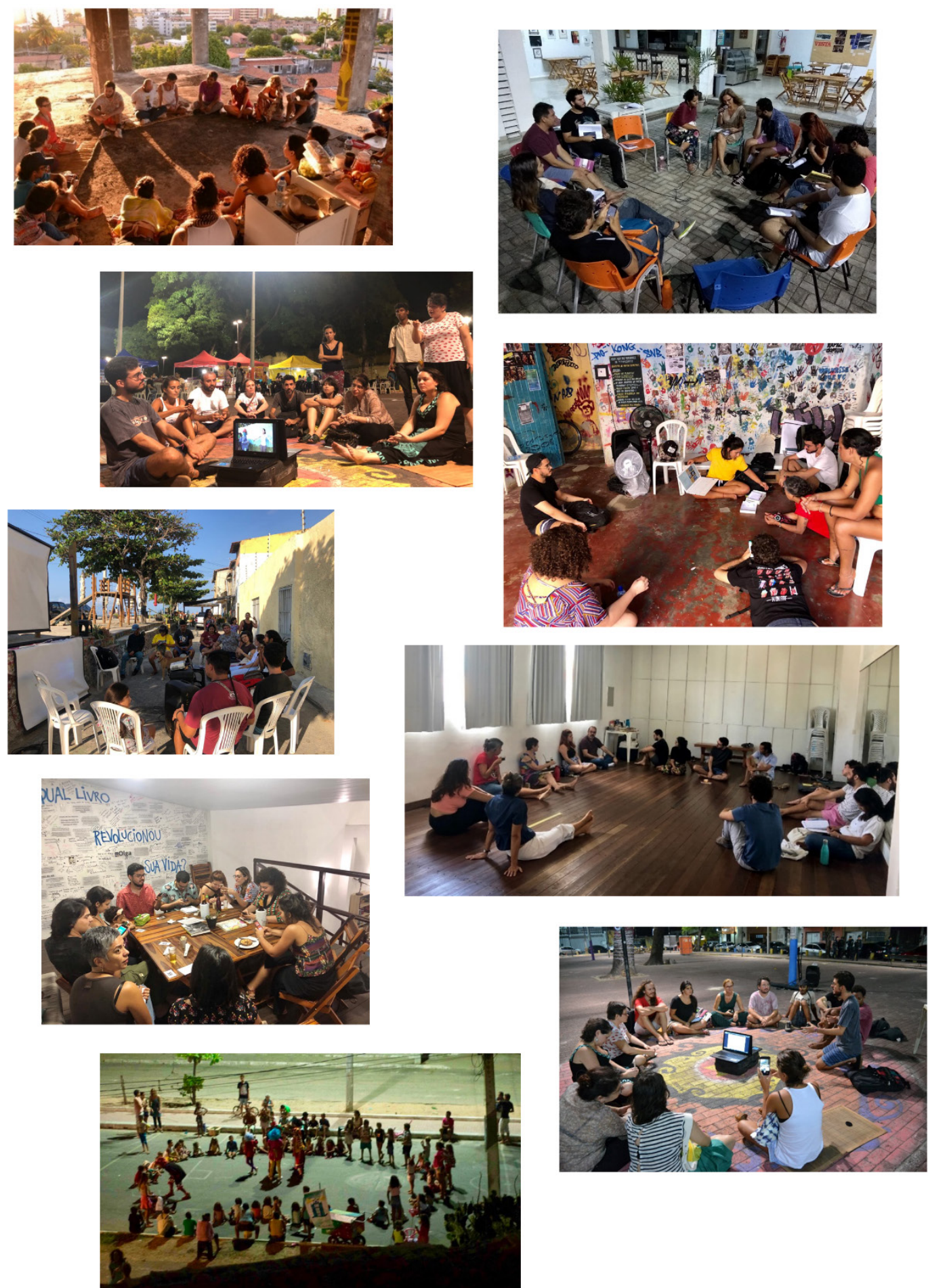

Figura 2 - Modos de intervir e pesquisar com. Fonte: Acervo do LAMUR. 

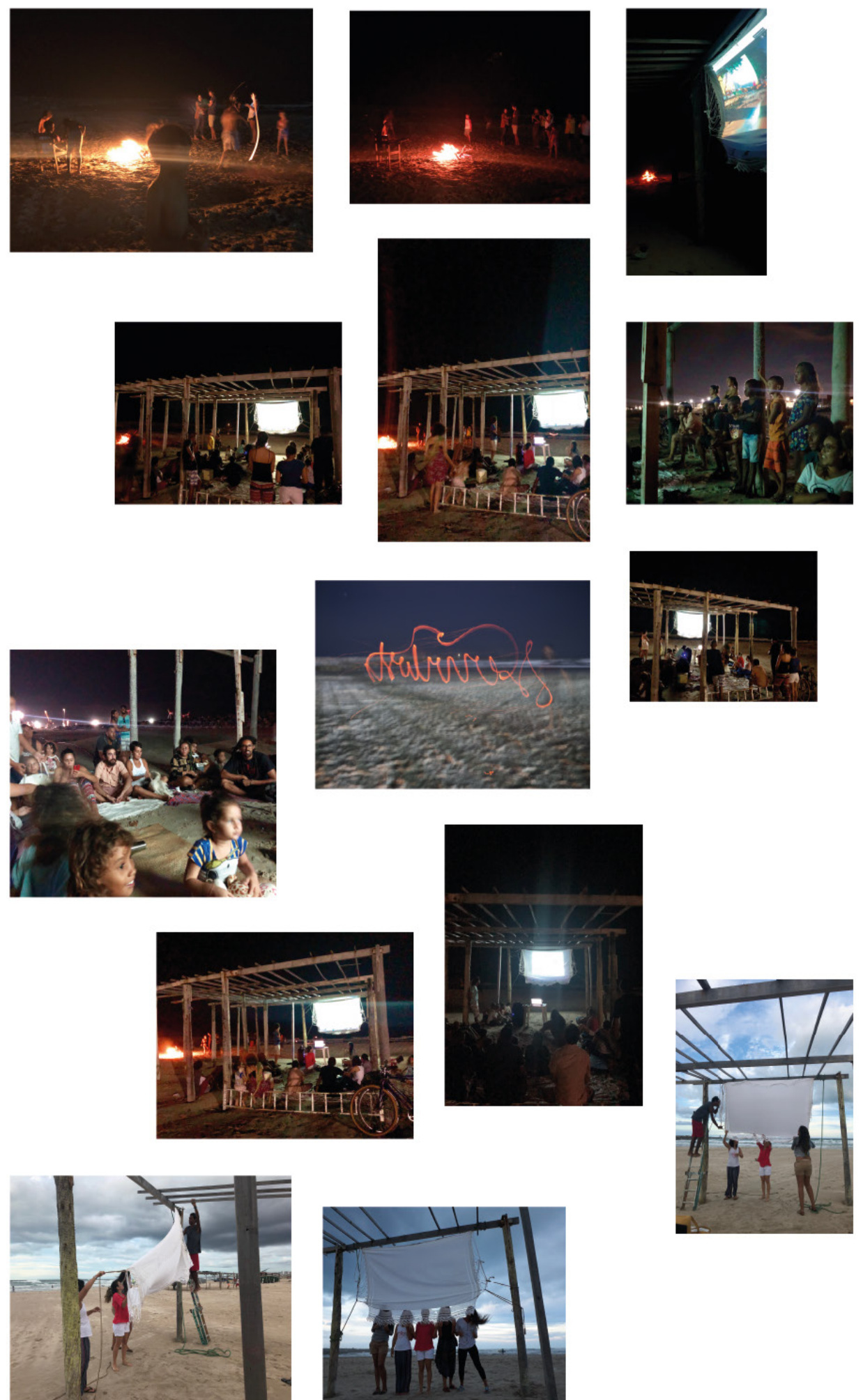

Figura 3 - ConversAções na Praia do Vizinho. Fonte: Acervo do LAMUR.

Iluminuras, Porto Alegre, v. 22, n. 56, p. 23-53, junho, 2021. 

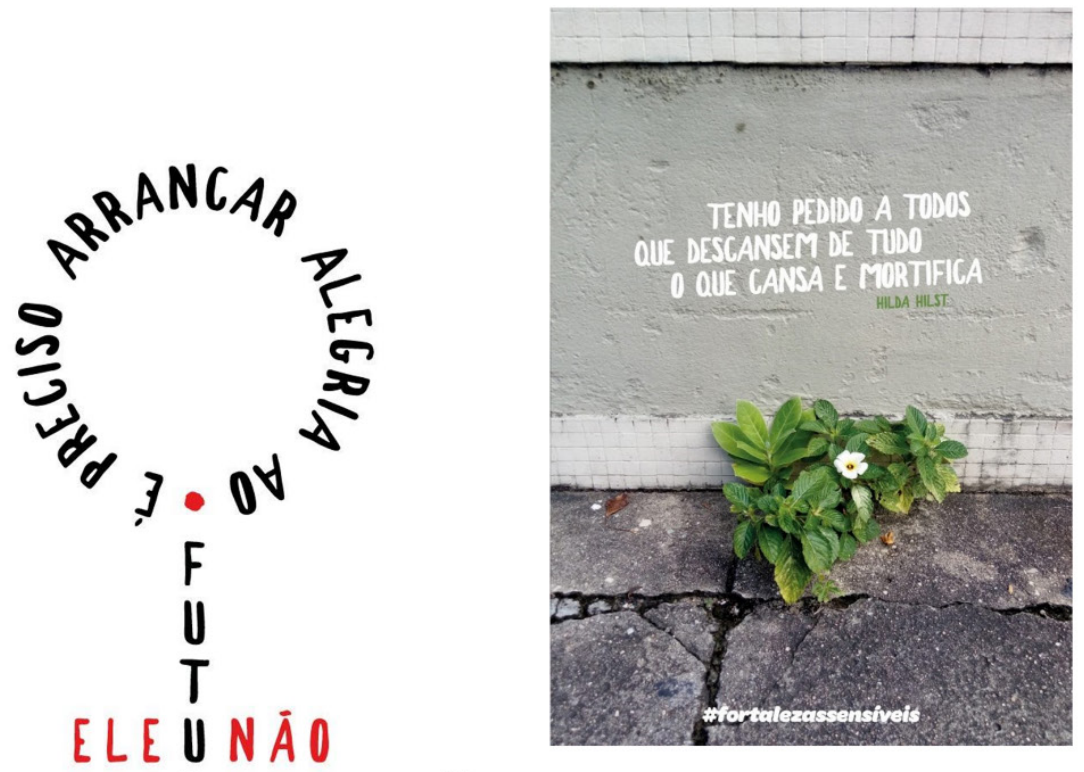

R

0

产
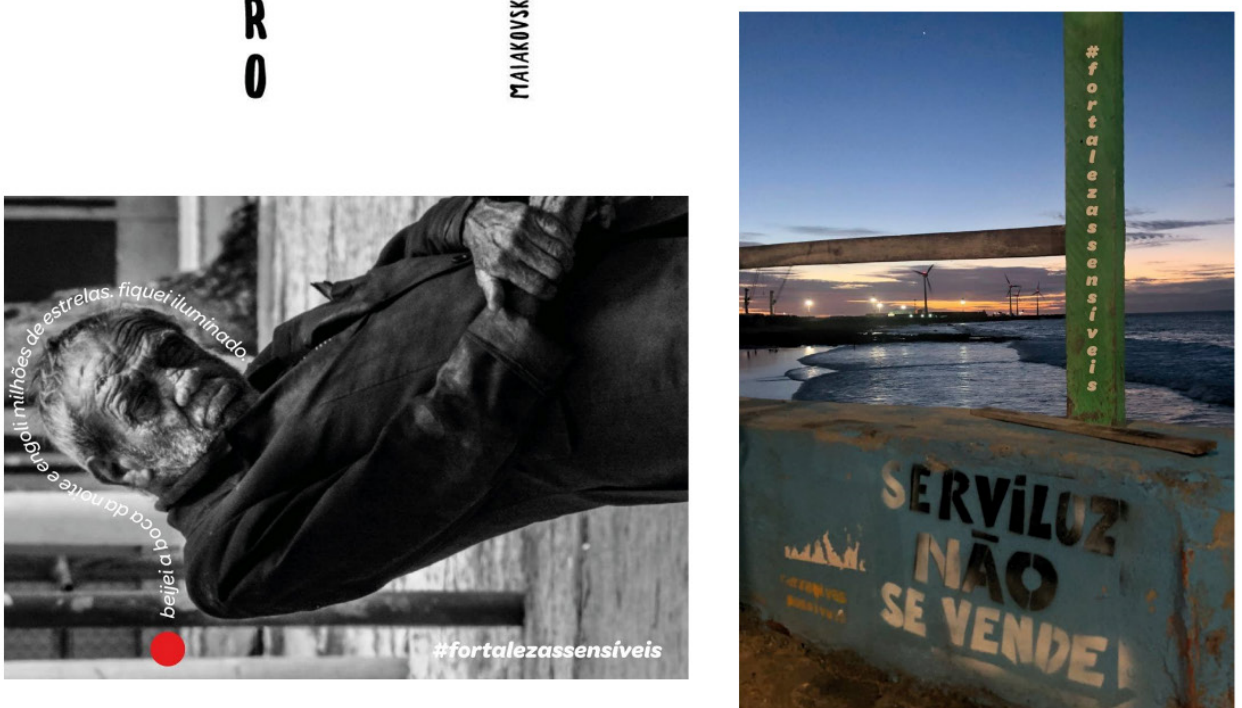

Figura 4 - Imagens produzidas para intervenção Micropolítica e Revolução. Fonte: Acervo do LAMUR. 

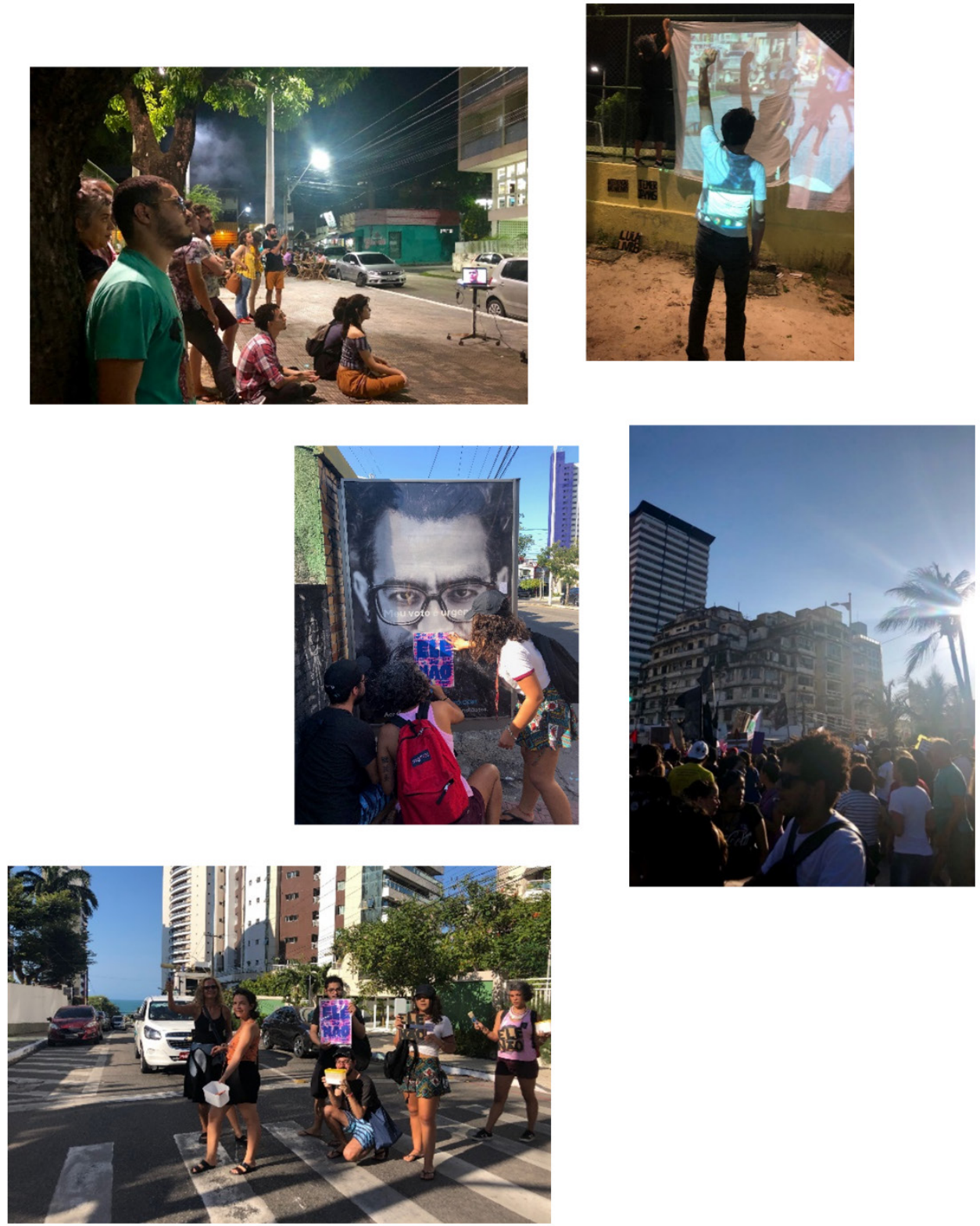

Figura 5 - Modos de intervir e inventar cidades. Fonte: Acervo do LAMUR.

\section{ConversAções na Praia do Vizinho}

ConversAções são convites ao encontro com as IntenCidades, que tomam corpo e inventam afetos, trazendo à tona os processos de criação e as pesquisas e intervenções nas artes em diálogo com a cidade, com questões que nos instigam a pensar e partilhar experiências com as Fortalezas Sensíveis. Encontros para conversar, no sentido de dar voltas com colaboradores e convidados, e com outros que de algum modo 
percebemos ao nosso redor, nas cercanias de nossa vizinhança, por também realizarem ações de pesquisa e intervenção com espaços-tempos urbanos (Gorczevski; Lima, 2017).

Do ano de 2016 a 2019, foram realizados dez ConversAções, ligados a diferentes pesquisas ${ }^{11}$ do LAMUR. Concebemos o "conversar", as "conversações" e as "redes de conversação" no sentido de distinguir os espaços e as modalidades de expressão, circulação e partilha, considerando as conversações no âmbito das ações e relações entre acadêmicos e não acadêmicos, artistas e não artistas, oficineiros e não oficineiros. Uma de nossas referências para pensar em "redes de conversação" foram os estudos de Humberto Maturana, nesse caso, principalmente, sua teoria da Biologia do Conhecer $(2001 ; 1999 ; 1995-1996)$. Nessa proposição, o autor analisa e conceitua o termo “conversar" como sendo o fluir que entrelaça o "linguajar e o emocionar".

Como seres humanos, crescemos e vivemos em coordenações consensuais de emoções e coordenações consensuais de coordenações consensuais de ações, que se entrelaçam umas às outras e formam redes fechadas de coordenações consensuais de emoções e linguagem. Nestas redes fechadas de coordenações consensuais de emoções e linguagem, nossas ações e o fluxo de nossas ações na linguagem mudam ao mudarem nossas emoções, e nossas emoções e o fluxo de nosso emocionar mudam ao mudarem nossas coordenações de ações na linguagem. Chamo de conversação nossa operação nesse fluxo entrelaçado de coordenações consensuais de linguajar e emocionar e chamo de conversações as diferentes redes de coordenações entrelaçadas e consensuais de linguajar e emocionar que geramos ao vivermos juntos como seres humanos (Maturana, 2001: 131).

O ConversAções na Praia do Vizinho foi uma realização conjunta do LAMUR, da Associação dos Moradores do Titanzinho ${ }^{12}$, do Coletivo AudioVisual do Titanzinho $^{13}$, do Cine Ser Ver Luz ${ }^{14}$ e do Projeto de Vida, do Instituto Trêsmares ${ }^{15}$, em 17 de abril de 2018.

A Praia do Vizinho é uma das praias do bairro Serviluz que, segundo a divisão político-administrativa municipal, não existe como tal. Com o nome escolhido pelos moradores, migrantes e pescadores, tecido por memórias e histórias de vida de diferentes

\footnotetext{
${ }^{11}$ A saber, Arte | Espaço Comum | IntenCidades (2014-2016), Cinema In(ter)venção - Cine Ser Ver Luz (2017-) e Fortalezas Sensíveis: Intervenções com a Cidade (2017-2019).

${ }^{12}$ Atuante no bairro Serviluz, em Fortaleza, desde 1986, tem sido construída de forma colaborativa, em mutirões que envolvem moradores e líderes comunitários. É composta atualmente por jovens moradores do bairro, que agem em aliança com diversos coletivos e organizações sociais, como o LAMUR.

${ }^{13} \mathrm{O}$ Coletivo AudioVisual do Titanzinho vem atuando em aliança com a Associação de Moradores na organização das Mostras AudioVisuais e do cineclube Cine Ser Ver Luz.

${ }^{14}$ Mais informações sobre o Cine Ser Ver Luz e a Mostra AudioVisual do Titanzinho podem ser consultadas no site: https://cineclubeserverluz.wordpress.com/

15 Para mais informações sobre o instituto, que atua no bairro Serviluz desde 2015, acesse: https://linktr.ee/institutotresmares
} 
gerações que, ao longo dos anos ${ }^{16}$, ocuparam a região, o Serviluz está inserido tanto no bairro Cais do Porto como no Vicente Pinzón. Ou seja, por estar entre dois bairros, não tem seu nome reconhecido oficialmente no mapa da cidade. No entanto, além de ter sua existência afirmada e construída com sentido de um "pertencimento ativo" da população, o bairro tem subdivisões territoriais, reunindo moradores da Estiva, Favela do Farol, Titanzinho e Vizinho.

A praia do Vizinho, situada ao longo da Rua Pontamar e a barlamar do espigão da Praia do Titanzinho, compreende uma faixa extensa de mar, onde ocorre retenção de areia em decorrência dos fortes ventos e do transporte eólico de sedimentos, desde a praia para o interior, em alguns períodos do ano, causando soterramento das vias e, mais ainda, invadindo as casas e interferindo na já precária infraestrutura do bairro. Considerada Área de Preservação Permanente (APP), logo, de uso muito restrito e sem qualquer degradação da biota, a Praia do Vizinho sofre com o descaso do poder público e a ausência de políticas ambientais, sendo urgente atenção às demandas dos moradores por contenção das areias e dunas móveis, flora quase inexistente e a fauna que ainda resiste, oferecendo diferentes espécies de peixes, sem falar da necessidade de proteção à desova das tartarugas. Como nos sugere Lima (2019: 73), em escrita apresentada na Sessão Peixinho, do Cine Ser Ver Luz, realizada na Rua Pontamar: "Talvez a gente nunca saiba na pele o que é ser um peixe, uma nuvem ou um inseto, mas podemos aprender as histórias de como vivem no planeta - nossa grande vizinhança."

O bairro Serviluz e suas praias Titanzinho e Vizinho, em Fortaleza, não estão na rota de visita ou mesmo no percurso cotidiano da cidade, também por serem territórios que se configuram como "ilhas urbanas (...) onde conhecer implica a vontade e a decisão de ir cruzando as linhas de segregação e inventando percursos de conexão, por exemplo, com as potencialidades dos fazeres e saberes artísticos e comunicacionais" (Gorczevski; Soares, 2015: 200), que podemos ver nas ações que a Associação de Moradores, o Coletivo AudioVisual do Titanzinho e o LAMUR realizam, em aliança, convidando moradores, estudantes, artistas e pesquisadores, entre elas, o ConversAções na Praia do Vizinho, aqui apresentado.

\footnotetext{
${ }^{16}$ A ocupação data de assentamentos que ocorreram no fim da década de 1940 e início da década de 1950 , primeiros anos da construção do Porto do Mucuripe, que durou duas décadas, tendo crescido, na década de 70 , com a transferência de famílias que sofreram remoção de uma praia localizada nas proximidades (Nogueira, 2007; 2015).
} 
As escolhas dos espaços da cidade onde acontecem esses encontros recebem atenção especial justo por tornarem visíveis questões como a indiferença e o descaso com os espaços públicos em nossa cidade, questões que ardem em nós, pensando nas palavras de Mia Couto (2011) quando traz o incendiador de caminhos, que cartografa, desenhando na paisagem a marca de sua presença. Escreve com fogo a narrativa que é seu trajeto e, assim, sobrevivemos como "[...] eternos errantes, caçadores de acasos, visitantes de lugares que estavam por nascer" (Couto, 2011: 71).

As convidadas Fabíola Gomes, Iara Andrade, Nataska Conrado - instigadas por Deisimer Gorczevski - partilharam suas pesquisas, aventuras, invenções e experiências com o território do Titanzinho, com o Serviluz, com Fortaleza.

Fabíola Gomes (2017) apresentou "AudioVisuais que inventam o bairro: o Serviluz que insiste em fazer sua história", uma análise de três vídeos produzidos com o Serviluz que trazem à tona memórias e modos de vida de moradores, uma política de amizade e as ambíguas relações com a cidade. Essa pesquisa resultou em seu trabalho de conclusão do curso de Cinema e Audiovisual na Universidade Federal do Ceará. Fabíola é também graduada em Letras/Francês e integra o Coletivo AudioVisual do Titanzinho e a Associação de Moradores do Titanzinho.

Em "Me organizando posso desorganizar: Associação de Moradores do Titanzinho", a psicóloga Iara Andrade compartilhou uma proposta de apresentação da história e dos objetivos da associação para novos integrantes, fruto do trabalho coletivo de conclusão do curso de especialização em Psicologia Organizacional e do Trabalho, na Universidade de Fortaleza. Iara também atua no bairro com o Projeto de Vida.

Nataska Conrado, graduada em Comunicação Social e especialista em Jornalismo e Crítica Cultural, apresentou sua pesquisa " $\mathrm{O}$ avesso da caverna com a nuca do cinema", defendida no PPGArtes|UFC ${ }^{17}$, em que discute o cinema de rua como acontecimento de encontro e partilhas sensíveis, aproximando o Cine Ser Ver Luz, realizado com as ruas do Serviluz, com experiências de coletivos cineclubistas de outras cidades, como o Acenda uma Vela | Cine Jangada, Cineclube Ideário e o Tela Tudo Clube de Cinema.

\footnotetext{
${ }^{17}$ A dissertação de mesmo título foi defendida no mestrado em Artes da Universidade Federal do Ceará em 2018, sob orientação de Deisimer Gorczevski.
} 
Processos entre pesquisar e intervir que, como apresentaram as três convidadas na divulgação ${ }^{18}$ desse ConversAções, dão-se:

[...] com territórios afetivos, com amigos, com moradores e visitantes. Com audiovisuais e cinemas que inventam associações, bairros e cidades. Com um fim de tarde feito com céu de nuvens velozes a correrem para o continente nos dando uma noite com as estrelas. Com uma rede de dormir como tela. Com uma fogueira para aquecer os corpos em meio ao ventinho frio na beira do mar. Com o barulhinho das ondas e das crianças a brincarem entre o breu e a luz.

Artes de intervenção que se movem e se afirmam com as vontades de criar, fazer e viver momentos de partilha, com a sensação de que criamos todos juntos, com nosso encontro, outra dimensão.

\section{Micropolítica e Revolução}

Eis que surge um caminho urgente a desbravar. Focos de incêndios ameaçam os territórios de nossa pesquisa/expedição; é preciso agir sobre eles. Estamos em 2018, pós-golpe jurídico-parlamentar que destituiu uma presidenta legitimamente eleita e posteriormente inocentada, e às vésperas de uma eleição para presidente em que o candidato favorito nas pesquisas faz homenagem a um reconhecido torturador do período da ditadura militar no Brasil. O fascismo espreita a sociedade, e a sociedade flerta com ele.

É também o ano em que se comemora o centenário da Revolução Russa e os 50 anos do maio de 68 na França, dois marcos revolucionários que colorem nosso imaginário com a paleta onírica da utopia. E, se essa memória histórica nos move e nos comove, romanticamente, não podemos nos dar ao luxo de ser ingênuos. A ingenuidade é também um crime em tempos de ameaça fascista.

No Brasil, 1968 é o auge da ditadura militar, ano do assassinato do estudante Edson Luís do Nascimento, o que representou o estopim para as maiores manifestações de rua do período, entre elas, a "Passeata dos Cem Mil". Em dezembro daquele ano foi decretado o Ato Institucional $\mathrm{n}^{\mathrm{o}} 5$ (AI-5), que fechou o Congresso Nacional e inaugurou um dos momentos mais sombrios de nossa história. É, portanto, inadmissível e

\footnotetext{
${ }^{18}$ Mais informações sobre as pesquisas apresentadas, além dos minicurrículos das pesquisadoras, estão disponíveis no seguinte link:
} 
repugnante que, hoje, o presidente da república reivindique o "direito" de comemorar a ditadura militar, e mais absurdo ainda o fato de que esse direito lhe seja concedido.

Em momentos extremos como as ditaduras, ou como a pandemia que atravessamos agora, as expressões artísticas ganham a dimensão de uma espécie de guerrilha sensível, capaz de mobilizar e, ao mesmo tempo, acolher nossa condição humana em sua complexidade. A canção "E a revolução", cujo trecho reproduzimos a seguir, é um exemplo da arte produzida na trincheira de uma guerra contra a ditadura, escrita pelo músico e compositor gaúcho Nei Tejera Lisboa ${ }^{19}$ (E a revolução, 2001):

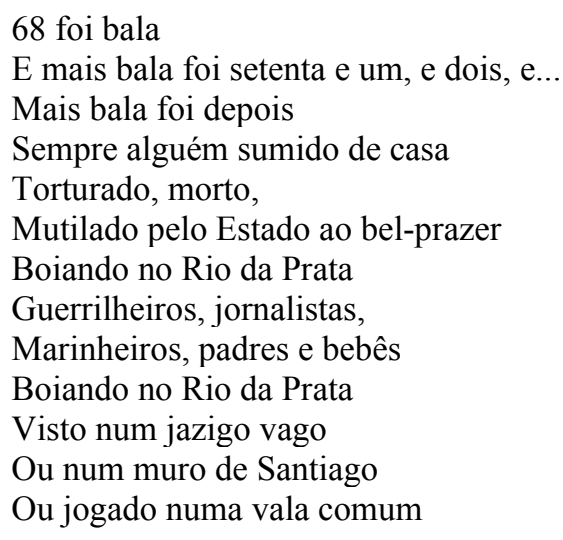

Diante da memória e da permanência desses episódios, nos perguntamos onde nos encontramos, anos depois desses acontecimentos? Como pensamos revolução hoje? Como não deixamos de pensar revolução, apesar da impossibilidade historicamente comprovada? Talvez por acreditarmos que revolução seja algo também semovente, que se transforma no tempo, como os territórios que pesquisamos.

Nos acompanham nesta trilha, entre outras, as leituras de "A Revolução Molecular”, de Félix Guattari (1987) e conceitos de micropolítica, molecular e molar, assim como utopia, em estudos realizados entre nós com as contribuições de Mário Pedrosa:

Para chegar à Utopia é preciso percorrer um caminho quase que infinito. Por isso mesmo, há um paradoxo da técnica em relação à comunicação: quanto mais aumenta a tecnologia, quanto mais meios de comunicação se obtém, mais confusa é a situação, mais maleável é a imagem que se procura. Não se encontra mais um só sentido, mas muitos sentidos variáveis e contraditórios. (Pedrosa, 1981: 10).

\footnotetext{
19 O irmão de Nei Lisboa, Luiz Eurico Tejera Lisboa, foi o primeiro desaparecido político brasileiro, cujo corpo pôde ser localizado no final dos anos setenta, depois de incansável busca.
} 
Em contraposição à utopia, esse "lugar que não existe", Michel Foucault nos convida a olhar para os lugares outros que existem, as heterotopias. Nos movimentos do tempo e espaço, "[...] toda sociedade pode perfeitamente diluir e fazer desaparecer uma heterotopia que constituíra outrora, ou então, organizar uma que não existisse ainda" (Foucault, 2013: 22).

Outra inspiração vem com "A Sobrevivência dos Vaga-lumes”, de Georges Didi-Huberman (2011). Os três nos instigam com suas críticas lúcidas e nada ingênuas, e na crença da potência (micro)revolucionária dos encontros, do convívio.

\begin{abstract}
Ainda que beirando o chão, ainda que emitindo uma luz bem fraca, ainda que se deslocando lentamente, não desenham os vaga-lumes, rigorosamente falando, uma tal constelação? Afirmar isso a partir do minúsculo exemplo dos vaga-lumes é afirmar que em nosso modo de imaginar jaz fundamentalmente uma condição para nosso modo de fazer política. A imaginação é política, eis o que precisa ser levado em consideração. (Didi-Huberman, 2011: 60).
\end{abstract}

Outro modo de pensar em revolução, hoje, é nos aproximarmos do pensamento de Ailton Krenak (2019), em "Ideias para adiar o fim do mundo", e Davi Kopenawa (2015), em “A Queda do Céu”, escrito com Bruce Albert. A literatura indígena contemporânea nos implica enquanto natureza, e dessa forma não há outra saída a não ser nos colocarmos todos contra o modelo econômico neoliberal que há tempos ameaça a sobrevivência sobre a terra. Assim diz Krenak (2019: 49): “Quando despersonalizamos o rio, a montanha, quando tiramos deles seus sentidos, considerando que isso é atributo exclusivo dos humanos, nós liberamos esses lugares para que se tornem resíduos da atividade industrial extrativista".

De modo análogo, quando nos omitimos do comprometimento estético e social, portanto político, com as cidades que coabitamos, liberamos a sua exploração para o modelo desenvolvimentista, que inclui uma especulação imobiliária perversa, dentre outras práticas adoecedoras impostas pela lógica neoliberal. Em meio a todas as agitações políticas que traziam à tona conservadorismo e violência no Brasil, fomos impulsionados a criar as ações Micropolítica e Revolução $(M+R)$.

Tendo as micropolíticas com a rua como temática, na resistência de protestos, atos, manifestações e ocupações, em março de 2018 lançamos um convite para o envio de fotografias e vídeos desses acontecimentos, para uma projeção audiovisual colaborativa na praça da Gentilândia, no bairro Benfica. As projeções colaborativas são artes de intervenção que, semelhante às manoeuvres, concretizam-se somente mediante 
adesão e partilha de outras pessoas; retomando, ainda, Oiticica e Clark, precisam do envolvimento do público "participador".

Recebemos mais de 130 fotografias e 10 vídeos, a maioria de Fortaleza e outras também de Brasília, Porto Alegre e São Paulo. A projeção colaborativa foi realizada pari passu com a apresentação de Joana Schroeder, colaboradora do LAMUR na pesquisa Arte | Espaço Comum | IntenCidades (2014-2016), da pesquisa intitulada "Entre pimentas e vinagres: violência, direitos humanos e (des)ordem nas manifestações no Brasil"20. Por imprevistos técnicos, a projeção foi adaptada para uma "microprojeção", com o apoio de dois notebooks, criando uma roda - um modo de fazer recorrente nas ações do LAMUR - entre os 20 participantes. Durante a conversa, houve uma intensa partilha de relatos do envolvimento daqueles ali presentes nos protestos que estavam em projeção, assim como questionamentos sobre os impactos àquela praça e às sociabilidades do bairro de uma chacina ali ocorrida, dias antes.

Esse foi o ensejo para o Micropolítica e Revolução: Gentilândia gera Gentilândia, em maio de 2018, em outra praça da vizinhança. Também com uma projeção colaborativa, indagamos na convocatória: quais Gentilândias estão presentes em nossos corpos-memórias? Com interesse sobretudo na resistência pelos afetos e os encontros, e nas micropolíticas acionadas pelo desejo e pelo que nos faz querer viver, acolhemos mais de 120 fotografias de feiras, carnavais, beijos e mesas de bar, famílias e brincadeiras de crianças, assim como de protestos que tiveram aquela praça como palco. Projetadas na fachada de uma das residências universitárias da Universidade Federal do Ceará, as imagens atraíram frequentadores da praça para assistir conosco à ode colaborativa. Ao mesmo tempo, em telão montado no alambrado da quadra da praça, projetamos novamente as imagens de protestos do primeiro $\mathrm{M}+\mathrm{R}$.

Gestou-se o desejo por um Micropolítica e Revolução 3 nas semanas que antecederam o período de campanha eleitoral no Brasil. Um assassinato, uma facada, prisões e uma investigação recheada de delações foram alguns dos marcos que evidenciaram o despontar de uma força política de direita, beirando o fascismo. Para o dia 29 de setembro de 2018 estava agendado o ato nacional das Mulheres que lutam por um mundo sem Fascismo, visando a promover a campanha Ele Não, contra o então candidato à presidência Jair Bolsonaro, por seus posicionamentos machistas, racistas e

\footnotetext{
${ }^{20}$ Título de sua dissertação, defendida em 2017 no mestrado em Relações Internacionais pela PUC-RJ, que pode ser acessada no link: https://www.maxwell.vrac.puc-rio.br/29971/29971.PDF
} 
LGBTfóbicos. Os participantes da pesquisa Fortalezas Sensíveis: Intervenções com a Cidade e do LAMUR decidiram por realizar o $\mathrm{M}+\mathrm{R} 3$ durante a manifestação em Fortaleza, novamente ativando uma intervenção junto à cidade, desta vez no corpo a corpo, com materiais para muros e postes e para ornar no peito.

Nossas inspirações para cartazes para lambe e adesivos foram poesias de Mário Gomes ("Beijei a boca da noite e engoli milhões de estrelas. Fiquei iluminado") e Hilda Hilst ("Tenho pedido a todos que descansem de tudo o que cansa e mortifica"), frases do russo Vladimir Maiakovski ("É preciso arrancar alegria ao futuro") e Nise da Silveira ("É necessário se espantar, se indignar e se contagiar. Só assim é possível mudar a realidade"), combinadas com a foto de Mário Gomes; o stencil "Serviluz não se vende", aplicado e fotografado na praia do Titanzinho, no bairro Serviluz; o símbolo de Vênus; e a cena histórica da garota que rejeitou apertar a mão do presidente-ditador João Figueiredo em 1979, junto a outras imagens produzidas por integrantes do LAMUR.

Além da impressão dos materiais para o dia da manifestação, os arquivos digitais foram disponibilizados para download no Facebook do LAMUR ${ }^{21}$, criando possibilidades de mais pessoas conhecerem e, caso tivessem interesse, espalharem essas políticas|poéticas visuais.

Em 29 de setembro, o grupo se reuniu para produzir plaquinhas de papelão ${ }^{22}$, que foram somadas aos cartazes para lambe e adesivos. Caminhando a pé da Avenida Santos Dumont à Praia de Iracema, lugar de concentração do ato, o grupo percorreu 2,9 $\mathrm{km}$, cantando e espalhando poesias por postes, muros, portões e paradas de ônibus. $\mathrm{Na}$ praia, o grupo se juntou à multidão colorida e diversa que ali se posicionava, feito mar de gente, contra o fascismo, o machismo, a homofobia e a violência, e que clamava por "arrancar alegria ao futuro".

As agitações políticas, o clima de guerra e o resultado das eleições presidenciais de 2018 deram sensação de estarmos num barquinho em meio à tormenta, mas ainda assim num mesmo barquinho, juntos. E juntos queríamos conversar.

O dispositivo para esse encontro foi o chamado nacional de movimentos e coletivos para que cada eleitor levasse um livro no dia do segundo turno de votação. Com a pergunta "Que livro você escolheu para levar no dia da eleição?”, lançou-se convite

\footnotetext{
${ }^{21}$ Disponível em https://www.facebook.com/lamurufc/posts/1809854432385068/

${ }^{22}$ As plaquinhas são parte da proposição AGITPROP, de Aline Albuquerque, que começou com mensagens políticas em plaquinhas de papelão, barbante e tinta preta em protestos de 2016, carregando as plaquinhas junto ao corpo, e que têm se tornado experiências coletivas em atos, ocupações e exposições em Fortaleza e outras cidades do país.
} 
para o Micropolítica e Revolução: Livrerdade - Livros Companheiros. Realizado em 19 de novembro de 2018, na Escola Porto Iracema das Artes, em Fortaleza, o encontro foi aberto para convidados e aconteceu em aliança com o Laboratório de Arte Contemporânea - LAC (ICA-UFC), tendo como moderadora Carmen S. de Oliveira ${ }^{23}$, psicóloga e ativista em direitos humanos.

Carmen instigou um momento de partilha, em que foi vital a escuta ativa e sensível das falas de cada um presente, dando vazão às experiências vividas de "mau tempo" no contexto político-eleitoral e suas expressões nas ruas, e aos modos de resistir e atentar para o que estaria por vir.

\section{Seguimos a pesquisar e intervir}

Ao pensar os modos de pesquisar e intervir com a cidade, evidenciam-se desafios presentes, desde a constatação da complexidade das mutações nos modos de conhecer e se relacionar com as artes na contemporaneidade, em especial, considerando questões que rompem com as linguagens clássicas e a emergente hibridização de gêneros, na perspectiva de um pensamento transdisciplinar da arte.

As relações entre artista e participador, que movimentam os trabalhos de Hélio Oiticica, e as tensões com o "lugar" do artista, do público e da arte, que Doyon/Demers (2009) e Richard (2014) discutem com as manoeuvres, trazem questões potentes que instigam os modos com que as artes inventam cidades.

E é com esse desafio que propomos dar continuidade aos estudos e intervenções, enunciando alguns desdobramentos na perspectiva de cidades sensíveis, anacrônicas, inventadas e insistentes: a proposição da pesquisa Fortalezas Sensíveis: Escritas com a Cidade - apresentada ao Programa de Pós-Graduação em Artes da Universidade Federal do Ceará; e, em especial, a criação do Ateliê de Escrita Inventiva, instigando experimentações com as cidades em devir (Deleuze, 1997) e a partilha dos processos de criação coletivos e singulares.

Nos encontros do Ateliê, realizados em plataformas online desde o início da pandemia de COVID-19, estamos estudando nossos processos de escrita inventiva, considerando a noção de escritura, dialogando com Roland Barthes, Gloria Anzaldúa,

\footnotetext{
${ }^{23}$ Carmen S. de Oliveira é uma aliada do LAMUR, tendo sido convidada para outras ações, como o encontro ConversAções: Brasil, além do ressentimento, realizado em agosto de 2017, em Fortaleza.
} 
Conceição Evaristo, Octavia Butler, Mia Couto, Luciano Bedin da Costa, Maria Gabriela Llansol, Béatrice Fraenkel e outras tantas leituras inspiradoras.

A composição deste trabalho sugere um exercício artístico-científico que afirme o pesquisar e o escrever como ato político:

[...] produzirmos - com nossos textos - mecanismos de resistência à santa trindade "escrever-publicar-produzir", de pensarmos a escrita e a leitura capazes de não apenas responder aos ditames desses tempos-textosmercadoria, mas em instaurar-lhes vacúolos de silêncio, zonas de dispersão e desvio que possam fazê-los tomar outros cursos, ex/cursionar. (Costa, 2017: 26-27).

E assim seguimos em pesquisa/expedição. Interessa-nos problematizar o que se entende por escrita e escritura na perspectiva de mapear os agenciamentos entre texto e contexto, assim como marcas e intensidades nos modos de habitar espaços da/com a cidade. Propomos um ex/cursionar com as artes de resistir, intervir e inventar cidades.

\section{REFERÊNCIAS}

ANDRADE, L. A. B.; SILVA, E. P.; LONGO, W. P. E.; PASSOS, E. A utopia da poiesis universitária. Revista Educação Brasileira do Conselho de Reitores das Universidades Brasileiras - CRUB, Brasília, v. 24, n. 48 e 49, p. 61-78, 2002. Disponível em: http://www.waldimir.longo.nom.br/artigos/106.doc. Acesso em: 10 mar. 2020.

BARROS, Manoel de. Livro sobre nada. São Paulo, Alfagarra, 2016.

BASBAUM, Ricardo. Manual do Artista-etc. 1 ed. Rio de Janeiro, Beco do Azougue, 2013. . O artista como pesquisador. Concinnitas, Rio de Janeiro, v. 1, p. 70-76, 2006.

BRITTO, Fabiana Dultra; JACQUES, Paola Berenstein. Corpocidade: arte enquanto microresistência urbana. Fractal: Revista de Psicologia, Niterói, v. 21, n. 2, p. 337-350, maio/ago. 2009. Disponível em:

https://www.scielo.br/pdf/fractal/v21n2/10.pdf. Acesso em: 12 fev. 2021.

CARERI, Francesco. Walkscapes: O caminhar como prática estética. São Paulo, Editorial Gustavo Gili, 2013. 
. Caminhar e parar. Trad. Aurora Fornoni Bernardini. São Paulo, Editorial Gustavo Gili, 2017.

COSTA, Luciano Bedin da. Aos que ainda escrevem: a escrita acadêmica nos designs do neoliberalismo. Linha Mestra, Campinas, n. 33, p. 21-28, set./dez. 2017. Disponível em: https://linhamestra0033.files.wordpress.com/2018/01/03_luciano_bedin_da_costa.pdf. Acesso em: 08 mar. 2021.

COUTO, Mia. Incendiador de Caminhos. In: . E se Obama fosse africano? E outras intervenções. São Paulo, Companhia das Letras, 2011. p. 69-76.

DELEUZE, Gilles. Crítica e Clínica. Trad. Peter Pal Perbart. São Paulo, Editora 34, 1997. . O ato de criação. São Paulo, Folha de São Paulo, 1987.

DELEUZE, Gilles; GUATTARI, Félix. Mil Platôs: Capitalismo e esquizofrenia. V. 1. São Paulo, Ed. 34, 2012. . Mil Platôs: Capitalismo e esquizofrenia. V. 5. São Paulo, Ed. 34, 1995. . Mil platôs: Capitalismo e esquizofrenia. V. 3. São Paulo, Ed. 34, 1996.

DIDI-HUBERMAN, Georges. Sobrevivência dos vaga-lumes. Trad. Vera Casa Nova e Márcia Arbex. Belo Horizonte, Editora UFMG, 2014.

DOYON, Hélène e DEMERS, Jean Pierre. Manobras: Viúvas de Caça. Revista Poiésis, Niterói, n. 13, p. 192-211, ago. 2009. Disponível em: http://www.poiesis.uff.br/PDF/poiesis13/Poiesis_13_manoeuvre.pdf. Acesso em: 15 jul. 2020.

E a revolução. Intérprete: Nei Lisboa. Compositor: Nei Lisboa. Porto Alegre: Antídoto, 2001. $1 \mathrm{CD}$, faixa 8. 
FAVARETTO, Celso. A invenção de Hélio Oiticica. 2. ed., $1^{\text {a }}$ reimpr. São Paulo, Editora da Universidade de São Paulo, 2015.

FONSECA, Tania M. G.; NASCIMENTO, Maria L. e MARASCHIN, Cleci (Orgs.).

Pesquisar na diferença. Um abecedário. Porto Alegre, Editora Sulina, 2012.

FOUCAULT, Michel. As heteroropias. In: O corpo utópico; as heterotopias. São Paulo, n1 Edições, 2013. p. 19-30.

GOMES, Maria Fabiola. Audiovisuais que inventam o bairro: o Serviluz que insiste em fazer a sua história. 2017. Monografia (Graduação em Cinema e Audiovisual) - Instituto de Cultura e Arte, Universidade Federal do Ceará, Fortaleza, 2017.

GORCZEVSKI, Deisimer e SOARES, Sabrina K. A. Ilhas que resistem: Titanzinho, em Fortaleza; Arquipélago. In: GORCZEVSKI, Deisimer (Org.). Arte que inventa afetos. 1. ed. Fortaleza, Imprensa Universitária - UFC, 2015. p. 187-202. Disponível em: http://www.repositorio.ufc.br/handle/riufc/15857. Acesso em: 25 fev. 2021.

GORCZEVSKI, D.; ALBUQUERQUE, A.; ARAÚJO, S. e SHIKI, C. Sobre poéticas e políticas: micro intervenções na cidade de Fortaleza. In: ENCONTRO REGIONAL DA ANPAP NORDESTE, 1; DIÁLOGOS INTERNACIONAIS EM ARTES VISUAIS, 4, 2015, Recife. Arte e Política [...]. Recife: Programa Associado de Pós-graduação em Artes Visuais UFPB/UFPE, Editora UFPE, 2015. p. 335-350. Disponível em: https://issuu.com/jmlima/docs/sobre_poeticas_politicas__micro_in . Acesso em: 15 jan. 2021.

GORCZEVSKI, D. e LIMA, J. M. D. de A. ConversAções: encontros entre as artes, a cidade e a universidade. Vazantes, Fortaleza, v.1 n. 2. p. 96-113, 2017. Disponível em: http://periodicos.ufc.br/vazantes/article/view/20499. Acesso em: 10 maio 2020.

GORCZEVSKI, D.; GOMES, M. F.; FERNANDES, P. e ARAÚJO, S. (Orgs.). Cinema que Inventa o Bairro: Cine Ser Ver Luz. 1 ed. Fortaleza, Imprensa Universitária, 2019.

Disponível em: http://www.repositorio.ufc.br/handle/riufc/45940. Acesso em: 6 mar. 2021. 
GORCZEVSKI, Deisimer e GOIS, Wilma Farias, Pesquisar e inventar: experiências com a observação e a cartografia. In: FRANCISCO, Deise Juliana; GORCZEVSKI, Deisimer e DEMOLY, Karla Rosane do Amaral. (Orgs.). Pesquisa em perspectiva: percursos metodológicos na invenção da vida e do conhecimento. Mossoró, EdUFERSA, 2014. p. 121156.

GUATTARI, Félix. Revolução Molecular: pulsações políticas do desejo. Tradução de Suely Rolnik. 3. ed. São Paulo, Brasiliense, 1987.

JACQUES, Paola Berenstein. Elogio aos errantes. Salvador, EDUFBA, 2012.

KASTRUP, Virgínia. O método da cartografia e os quatro níveis da pesquisa-intervenção. In: CASTRO, L. R. e BESSET, V. L. (Orgs.). Pesquisa-intervenção na infância e juventude. 1 ed. Rio de Janeiro, Nau, 2008, v. 1. p. 465-489.

. A atenção na experiência estética: cognição, arte e produção de subjetividade.

Revista TRAMA Interdisciplinar, São Paulo, v. 3, p. 23-33, 2012.

KOPENAWA, Davi; ALBERT, Bruce. A queda do céu: palavras de um xamã yanomami. Tradução de Beatriz Perrone-Moisés. São Paulo, Companhia das Letras, 2015.

KRENAK, A. Ideias para adiar o fim do mundo. São Paulo, Companhia das Letras, 2019.

LAZZAROTO, Gislei D. R. e CARVALHO, Julia D., Afetar. In: FONSECA, Tania M. G.; NASCIMENTO, Maria L. e MARASCHIN, Cleci (Orgs). Pesquisar a diferença. Um abecedário. Porto Alegre, Editora Sulina, 2012. p. 23-25.

LEMINSKI, Paulo. Distraídos Venceremos. 2.ed. São Paulo, Editora Brasiliense, 1990. . Toda poesia [quarenta clics em Curitiba; 1976]. São Paulo, Companhia das Letras, 2013.

LIMA, João Miguel. Natureza e[m] movimento. In: GORCZEVSKI, D.; GOMES, M. F.; FERNANDES, P. e ARAÚJO, S. (Orgs.). Cinema que inventa o bairro. 1 ed. Fortaleza, 
Imprensa Universitária, 2019, v. 1. p. 72-73. Disponível em:

http://www.repositorio.ufc.br/handle/riufc/45940. Acesso em: 18 mar. 2021.

MATURANA, H. R. e VARELA, F. J. El árbol del conocimiento: Las bases biológicas del entendimento humano. Santiago de Chile, Editora Universitária, 1990.

. De Máquinas e Seres Vivos: Autopoiese - A Organização do Vivo. Porto Alegre, Artmed, 1997.

MATURANA, Humberto. Ontologia da Realidade. Belo Horizonte, Editora UFMG, 1999.

. Cognição, Ciência e Vida Cotidiana. Belo Horizonte, Editora UFMG, 2001.

. La realidad: Objetiva o Construída. I Fundamentos biológicos de la realidad.

Volume I. Barcelona \& Cidade do México, Instituto Tecnológico y de Estudos Superiores de Occidente (ITESO), 1995-1996.

MBEMBE, Achille. Necropolítica. Arte \& Ensaios, Rio de Janeiro, n. 36, p. 122-151, dez. 2016. Disponível em: https://revistas.ufrj.br/index.php/ae/article/view/8993/7169. Acesso em 23 maio 2021.

MEIRELES, Cecília. Os melhores poemas de Cecília Meireles: Seleção Maria Fernanda. São Paulo, Global Editora, 2002.

NIETZSCHE, Friedriech. A vontade de poder. Trad. Marcos Sinésio Pereira Fernandes e Francisco José Dias de Moraes. Rio de Janeiro, Contraponto, 2008.

NOGUEIRA, André Aguiar. Fogo, vento, terra e mar: a arte de falar dos trabalhadores do mar. São Paulo, Secretaria de Cultura do Município de Caçapava, 2007.

. Da pesca ao surfe: natureza, cultura e resistência na praia do Titanzinho, em Fortaleza. In: GORCZEVSKI, Deisimer (Org.). Arte que inventa afetos. Fortaleza, Imprensa Universitária, 2015. p. 143-153. Disponível em:

http://www.repositorio.ufc.br/handle/riufc/15857. Acesso em: 25 fev. 2021. 
OITICICA, Hélio. Esquema geral da nova objetividade. In: FERREIRA, G. e COTRIM, C. (Orgs.). Escritos de artistas: anos 60/70. 2 ed. Rio de Janeiro, Zahar, 2009. p. 154-168.

PASSOS, Eduardo; KASTRUP, Virginia e ESCÓSSIA, Liliana da. (Orgs.). Pistas do método da cartografia. Pesquisa-Intervenção e produção de subjetividade. V. 1. Porto Alegre, Ed, Sulina. 2010.

PEDROSA, Mário. O pensamento vivo de Mário Pedrosa. Entrevista concedida a Lygia Pape, Ricky Goodwin, Jaguar, Ferreira Gullar, Darwin Brandão, Pelão, Ziraldo, Hélio Pellegrino, Félix de Athayde, Washington Noaves. Pasquim, Rio de Janeiro, ano XIII, n. 646, 12-18 nov. 1981. Disponível em: https://revistas.ufrj.br/index.php/ae/article/view/14513/9717. Acesso em: 10 abr. 2018.

PELLANDA, Nize Maria Campos. Sofrimento escolar como impedimento da construção de conhecimento/subjetividade. Educação \& Sociedade, Campinas, v. 29, n. 105, p. 10691088 , dez 2008.

e GUSTSACK, Felipe. Autonarrativas e invenção de si. In:

GORCZEVSKI, Deisimer (org.). Arte que inventa afetos. Fortaleza, Imprensa Universitária, 2015. p. 39-54. Disponível em: http://www.repositorio.ufc.br/handle/riufc/15857. Acesso em: 25 fev. 2021.

PINK, Sarah. From embodiment to emplacement: re-thinking competing bodies, senses and spatialities. Sport, education and society, v. 16, n. 3, p. 343-355, jun. 2011. Disponível em: http://dx.doi.org/10.1080/13573322.2011.565965. Acesso em 20 maio 2021.

RANCIÈRE, Jacques. A partilha do sensivel: Estética e política. São Paulo, Ed. 34, 2010. . O espectador emancipado. São Paulo, Martins Fontes, 2012.

RICHARD, Alain-Martin. Arte como não lugar. Tradução de Tradução de João Miguel D. de A. Lima. Vazantes, Fortaleza, v. 1, n. 2, p. 06-17, 2017. Disponível em: http://periodicos.ufc.br/vazantes/article/view/20469/30906. Acesso em: 27 fev. 2021. 
ROCHA, Enrico. Vizinhança. In: RIBAS, Cristina (Ed.). Vocabulário político para processos estéticos. Rio de Janeiro, 2014. p. 316-318. Disponível em:

https://vocabpol.cristinaribas.org/wp-content/uploads/2015/01/vocabpol_linkscompleto.pdf. Acesso em: 10 mar. 2020.

ROLNIK, Suely. Cartografia Sentimental. Transformações contemporâneas do desejo. São Paulo, Editora Estação Liberdade, 1989.

ROSA, João Guimarães. Tutameia (Terceiras histórias). Rio de Janeiro: Nova Fronteira, 2017.

VARELA, Francisco. Entrevista concedida a Rogério da Costa. In: COSTA, Rogério da (Org.). Limiares do Contemporâneo. São Paulo, Escuta, 1993.

. Conhecer: as ciências cognitivas: tendências e perspectivas. Lisboa, Instituto Piaget, 1994.

; THOMPSON, E. e ROSCH, E. De Cuerpo presente: las ciencias cognitivas y la experiencia humana. Barcelona, Gedisa, 1992.

Recebido: $22 / 03 / 2021$

Aprovado: 02/06/2021 